\title{
Floristic composition of the halophilic and salt-resistant plant population in Hammam-Boughrara (Oran-Algeria)
}

\author{
Amel Taleb-Bendiab Sari-Ali", Noury Benabadji, Mohamed Bouazza \\ Department of Biology and Environment, Faculty of Natural Sciences and Life and Earth Sciences and the Universe, Tlemcen Uni- \\ versity, Tlemcen, Algeria; ${ }^{*}$ Corresponding Author: talebamel@yahoo.fr
}

Received 10 February 2012; revised 11 March 2012; accepted 10 April 2012

\begin{abstract}
This phyto-ecological study is on halophilic and salt-resistant vegetation of Oran region. The semiarid and sometimes arid climate has been defined and confirmed from a bioclimatic point of view. The pedological approach used shows a soil with sandy to silty-sandy texture, favoring regression of the vegetation and a halophilic vegetation set up. In this study, we analyze the floristic composition of the northern region of Hammam Boughrara using multiple floristic surveys conducted at three stations along the Tafna wadi. Dominated by Mediterranean and Saharo-Sindian elements, the relatively poor flora (88 species in total) is biologically characterized by a clear dominance of therophytes (>33\%) and chamaephytes $(>19 \%)$ to the detriment of phanerophytes.
\end{abstract}

Keywords: Phyto-Ecology; Salt-Resistant Vegetation; Halophilic Vegetation; Botanical Characterization; Bioclimate; Hammam Boughrara; Oran (Algeria)

\section{INTRODUCTION}

The Maghreb has one of the most remarkable floras of the Mediterranean basin. This may explain its climatic, geographic and geological diversity. Algeria in general and Oran in particular, is an area characterized by significant plant diversity.

For a long time, the flora and landscape of this region have been coveted and reshaped by the cultivation and grazing. The area is located solely in a semi-arid and arid bioclimate, with a temperate winter; the area is also subject to problems related to continentality in western Algeria.

The vegetation of the Oranian saline soils has been studied by Simonneau [1], Dubuis and Simonneau [2,3] and Quézel and Simonneau [4], and its distribution relates to the soil salinity. The dominant plants are annual or perennial Salsolacea, forming either pure populations or associations, comparable to those described in the south of France [5].

In the Hammam-Boughrara region, vast areas of both Tafna wadi shores, unsuitable for cultivation, are covered with halophytes. These soils, saturated with $\mathrm{Na}^{+}$ions, are classified among Solonchak soils [6]. Their appearance is due to the phreatic water which deposits its salts on the surface during evaporation [2,7].

Knowledge of the natural vegetation, as a reflection of environmental conditions, should allow a diagnosis of the first face plant in these ecosystems.

The works in the region remain somewhat fragmented. We intend contribute floristic surveys that may be useful. The interpretation of the Oran halophilic populations is possible and effective in light of pre-forest formations derived from, because of the strong anthropic pressure exerted in the region. The area was also affected by drought from 1970 to 2000.

Through the various works done on this region $[8,9]$, we have tried to identify the halophytes phytoecology aspects in the Northwest of Algeria (North of HammamBoughrara). Can these aspects give us some suggestions for improving the disrupted flora capital? Do halophilic populations expanse exclusively on the North banks of Tafna wadi? In an attempt to answer to these questions, we will deal in this paper successively through:

Description of the physical environment;

Bioclimatic and edaphologic characters;

Floristic analysis.

\section{SITES AND METHODS}

\subsection{Location and Choice of Sites of Study (Figure 1)}

The study area is located in western Algeria and be- 
longs administratively to the wilaya of Tlemcen. It is naturally confined by the Traras Mountains on the northwest and the Tlemcen Mountains on the south. The Hammam Boughrara municipality (study area) is limited administratively:

- To the west by the municipalities of Maghnia and Djabala.

- To the south by the municipalities of Remchi and Sabra;

- To the east by the municipalities of Hennaya and Tlemcen;

- And to the north by those of Zenata and Remchi.

The choice of stations considered to be representative was made to reflect the greatest plant diversity of the study area and was directed by the presence of salt tolerant populations. Three sites were selected through a stratified sampling: Zenata, Remchi and Hammam Boughrara (Table 1).

These sites differ from each other by geographic location, topography, soil, anthropogenic factors and vegetal diversity.

\subsection{Bioclimatic Situation}

Belonging to the Mediterranean bioclimate, the northern region of Hammam Boughrara is characterized by dry periods that can last 6 to 7 months. The bioclimate of the region has been studied by Ghezlaoui $[8,10]$ and Bemmoussat [11]. The area receives winter Mediterranean drizzling rains which last longer than those in the summer. March and April rains are heavy and frequent, whereas January and February rainfalls are lighter, but more frequent.

Annual rainfall varies between $280 \mathrm{~mm}$ and $300 \mathrm{~mm}$ (with a maximum of $49 \mathrm{~mm}$ in March and a minimum of
$1.5 \mathrm{~mm}$ in July). This shows important variability between months and places.

The climate is semi-continental with a temperature range of about $27^{\circ} \mathrm{C}$. January is the coldest month $\left(9.5^{\circ} \mathrm{C}\right)$, and August the hottest $\left(29.2^{\circ} \mathrm{C}\right)$ [11].

The pluviothermic Emberger quotient $\left(\mathrm{Q}_{2}\right)$ [12] permits the halophilic populations to establish in the lower semi-arid and higher arid bioclimates with cool to temperate winter variation.

\subsection{Soils of the Region}

Soil studies, in North Africa in general and in this particular region, were carried out by Simonneau [13], Ruellan [14], Pouget [15], Alcaraz [16], Aimé [17] and Benabadji et al. [18].

The analytical results obtained on some soil samples in the three sites show:

- A sandy texture in Hammam Boughrara (72\% sand) and silty-sandy texture (17\% silt, 68\% sand) in Remchi and Zenata.

- A total lime content between $2.52 \%$ and $18.80 \%$ in the region of Remchi. Hammam Boughrara soils have higher $\mathrm{CaCO}_{3}$ content (above 25\%).

- The pH is basic in all the sites. It also records a value greater than 7 in all the samples.

- Salinity (electrical conductivity) varies from slightly salty to salty. The minimum thresholds are reached in Zenata region $(0.7$ and $0.8 \mathrm{mS} / \mathrm{cm})$, the upper limits are obtained in Hammam Boughrara with $1.21 \mathrm{mS} / \mathrm{cm}$.

- Organic matter is relatively low for all stations $(0.104 \%$ to $2.21 \%$.

- The color according to the Munsell code ranges from 5YR 5/6, 7.5 YR 6/6 and 10YR 6/4 for all the stations.

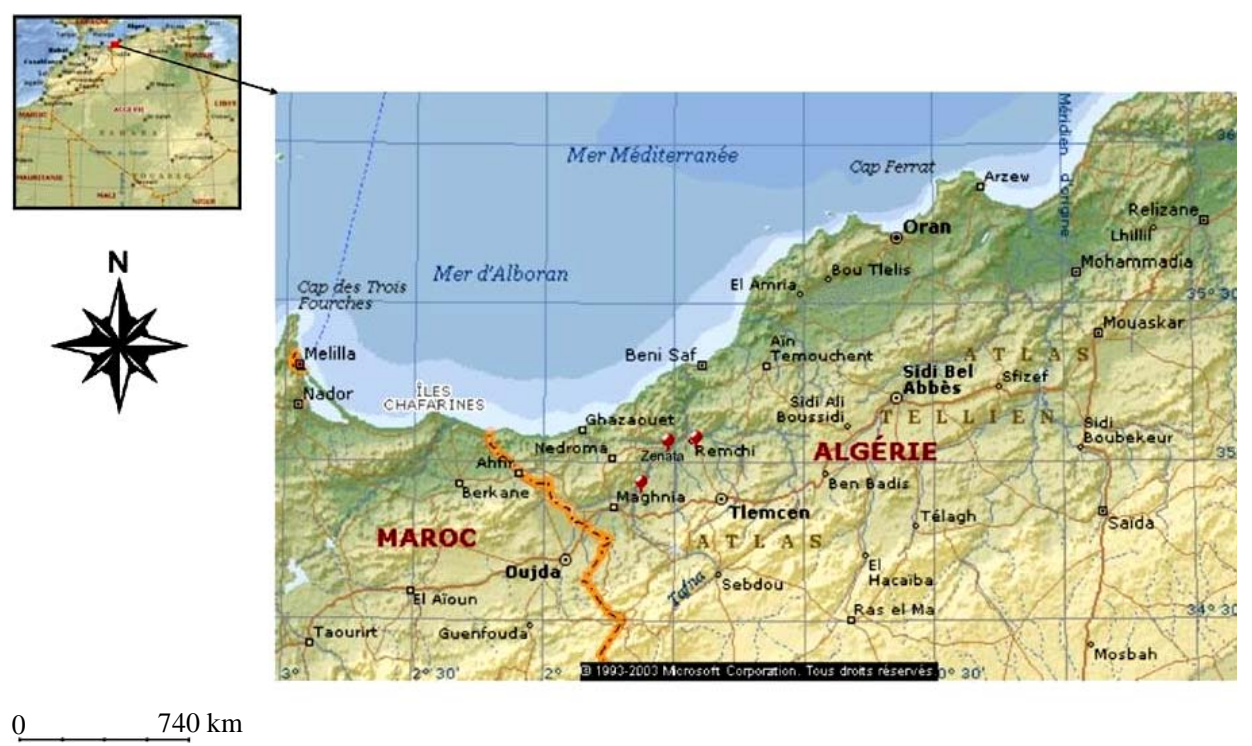

Figure 1. Geographical location of study sites. 


\section{METHODOLOGY}

\section{Floristic Surveys}

The vegetation of the study station indicates a preforest and halophilic physiognomy, except on some mountain slopes located further north (Traras Mountains). In this area, rainfalls may reach $400 \mathrm{~mm}$ annually. It also contains degraded remnant forests, formed by Pinus halepensis, Juniperus oxycedrus and Pistacia atlantica.

Floristic surveys were conducted in spring periods, in spaces occupied by the Chenopodiaceous, which spread over the borders of Tafna wadi and near cultivations.

The surface records must be sufficient to obtain almost all the species present, in the floristically homogeneous station, corresponding to the minimum area [19].

According to Quézel et al. [20] areas are from 100 to $400 \mathrm{~m}^{2}$ for forest communities, from 50 to $100 \mathrm{~m}^{2}$ for the scrubland formations and 20 to $50 \mathrm{~m}^{2}$ for herbaceous vegetation. For this survey we deliberately chose a $100 \mathrm{~m}^{2}$ area (minimum area).

During the survey, each identified species was affected by two indices; the first reflects the abundance-dominance and the second sociability. The presence and the number of individuals were also noted, using the Braun Blanquet method [21].

The determination of biological types of the 88 species recorded was based on the Raunkiaer method [22]. All life forms were considered, regardless of the different subdivisions for the size variation, morphology and arrangement of the various organs. We also determined morphological and biogeographic types. Inventoried taxa were identified from the Flora of Algeria [23], Sahara [24,25] and France [26].

\section{RESULTS AND INTERPRETATIONS}

\subsection{Floristic Surveys}

\section{- Zenata station (Table 1 in appendix)}

The conducted surveys allowed us to distinguish 02 major categories of plant species; nitratophiles and halophytes. Nitratophiles are mostly annual (Erodium moschatum, Sanguisorba minor, Papaver rhoeas, Avena sterilis...), and were strongly present in all surveys. They constituted grass areas, and infiltrated cultivated zones and Atriplex areas. Rich and varied, the halophilic group is dominated by Atriplex halimus, Salsola vermiculata, Suaeda fruticosa, Lygeum spartum and Arthrophytum scoparium. It is characteristic of Atriplico halimiSuaedetum fruticosae ass. nov. in Aimé [17] and SalsoloPeganion alliance. The rate of recovery varies from one place to another. In depressions, these populations reach $30 \%$ and become rare on the wadi beds. Malva sylvestris, Ziziphus lotus, Pallenis spinosa and companion species are poorly represented in the surveys.

- Remchi station, Tafna wadi (Table 2 in appendix)

At first glance, in this clump, an asymmetry emerges, resulting in a wooded, slightly inclined station and another with steep cleared slopes.

Surveys conducted along the banks of Tafna wadi show a diversified landscape infiltrated by pre-forest populations (Teucrium polium, Ampelodesma mauritanicum, Cistus albidus and Thymus ciliatus. Classes of TheroBrachypodietea [27] and Stellarietea mediae [28] are well represented with the following species: Muricaria prostrata, Aegilops triuncialis, Astragalus pentaglottis, Salvia verbenaca, Calendula arvensis, Plantago ovata etc. These species are mostly annual therophytes said nitratophiles. The use of fertilizers eliminates the most sensitive species and promotes the development of the nitratophilic ones. In this region, greenhouse crops are taking considerable hold. We distinguished these species, mixed in with those belonging to the Salsolatea vermiculatae class, the Atriplico halimi-Suaedetum fruticosae ass. nov. in Aimé [17] association and the SalsoloPeganion alliance. They are halophytes as Atriplex halimus, Salsola vermiculata, Lygeum spartum, Tamarix gallica and Suaeda fruticosa. The average height of Atriplex halimus shrubs may reach 2 meters high. The therophytes take place between Salsola and Atriplex shrubs; their size does not exceed $12 \mathrm{~cm}$. The Tamarix gallica species, surrounding the wadi edges, reaches 4 to $5 \mathrm{~m}$ high.

- Hammam Boughrara station (Table 3 in appendix)

The surveys were done at a study site in the immediate vicinity of an agricultural plain, part of the great plain of Angad extending to Fez in Morocco. Only this station has a tree stratum. Thin, but relatively diversified with Olea europea and Ceratonia silica, forming the Oleoceratonion alliance, and Acacia albida called now Faidherbia albida and Tamarix gallica. It is very likely that a regressive evolution of this ecosystem is occurring. The

Table 1. Location of study sites.

\begin{tabular}{cccccc}
\hline Study sites & Latitude & Longitude & Altitude & Municipality & Wilaya \\
\hline Zenata & $35^{\circ} 02^{\prime} \mathrm{N}$ & $1^{\circ} 33^{\prime} \mathrm{W}$ & $249 \mathrm{~m}$ & Zenata & Tlemcen \\
Remchi & $34^{\circ} 03^{\prime} \mathrm{N}$ & $1^{\circ} 24^{\prime} \mathrm{W}$ & $200 \mathrm{~m}$ & Remchi & Tlemcen \\
Hammam-Boughrara & $34^{\circ} 54^{\prime} \mathrm{N}$ & $1^{\circ} 37^{\prime} \mathrm{W}$ & $280 \mathrm{~m}$ & Maghnia & Tlemcen \\
\hline
\end{tabular}


number of encountered shrubs and bushes species, however, remains positive in this regressive dynamic state. The classes of Thero-Brachypodietea [26] and Stellarietea mediae [27] are well represented in this study station; they are annual or perennial grasses. An arid climate and the anthropozoogenic pressure means that halophytes are present with the Salsoletea vermiculatae class. We found, in particular, Atriplex halimus appearing in dense shrub forms. We also noticed Salsola vermiculata, Tamarix gallica, Frankenia corymbosa and Frankenia laevis.

\subsection{Floristic Analysis}

The study of vegetation (Table 2) is divided into 33 families. Figure 2 shows the distribution of these families for each station. In Remchi and Zenata stations, the plant family having the greatest diversity of flora was Cheno- podiaceae, followed by the Poaceae family. Hammam Boughrara is essentially characterized by the Asteraceae and Poaceae families (9 species).

\section{- Biological types}

In the literature [29-31] biological types are considered as a biological experience of the flora and vegetation adaptive strategy to environmental conditions. In each study station, the most dominant biological type corresponded to therophytes (Th) (Table 3).

The chamæphytes took the second dominant position. This chamæphytisation occurs due to the phenomenon of aridification [22,32,33]. In these halophilic and salt-resistant vegetations, the majority of the chamæphytes $(\mathbf{C h})$ met are Salsola vermiculata, Salsola foetida, Salsola sieberi, Arthrophytum scoparium, Atriplex halimus and Suaeda fruticosa.

Table 2. List of species present in North of Hammam Boughrara (Remchi, Zenata, Hammam-Boughrara).

\begin{tabular}{|c|c|c|c|c|c|}
\hline Dobignard “2007” & Quézel \& Santa 1962-1963 & $\begin{array}{c}\text { Families } \\
\text { Q \& S }\end{array}$ & $\begin{array}{l}\text { Biologic } \\
\text { types }\end{array}$ & $\begin{array}{l}\text { Morphological } \\
\text { types }\end{array}$ & $\begin{array}{l}\text { Biogeographic } \\
\text { types Q \& S }\end{array}$ \\
\hline Faidherbia albida (Delile) A.Chev. & Acacia albida & Mimosées & $\mathrm{Ph}$ & L.V & Afr. Trop. \\
\hline Aegilops cf. triuncialis L. & Aegilops triuncialis & Graminées & Th & H.A & Méd. Irano. Tour. \\
\hline Aeluropus cf. littoralis (Gouan) Parl. & Aeluropus littoralis & Graminées & Ge & H.V & Circumméd. \\
\hline Agave americana $\mathrm{L}$. & Agave americana & Amaryllidacées & Ge & L.V & Naturalisé \\
\hline $\begin{array}{l}\text { Elytrigia atherica (Link) M.A.Carreras ex } \\
\text { Kergu }\end{array}$ & Agropyrum littorale & Graminées & $\mathrm{Ge}$ & H.V & End. \\
\hline Allium roseum $\mathrm{L}$. & Allium roseum & Liliacées & Ge & H.V & Méd. \\
\hline Ammoides pusilla (Brot.) Breistr. & Ammoides verticillata & Ombellifères & Th & H.A & Méd. \\
\hline $\begin{array}{l}\text { Ampelodesmos mauritanicus (Poir.) } \\
\text { Durand \& Schinz }\end{array}$ & Ampelodesma mauritanicum & Graminées & $\mathrm{Ch}$ & H.V & W. Méd. \\
\hline Anagallis $c f$. arvensis L. & Anagalis arvensis & Primulacées & Th & H.A & Sub. Cosmop. \\
\hline Artemisia herba-alba Asso & Artemisia herba-alba & Composées & $\mathrm{Ch}$ & L.V & $\begin{array}{l}\text { Esp. des canaries à } \\
\text { l’Égypte, Asie Occ. }\end{array}$ \\
\hline Hammada scoparia (Pomel) Iljin & Arthrophytum scoparium & Chénopodiacées & $\mathrm{Ch}$ & H.V & Sah. Méd. \\
\hline Asparagus acutifolius L. & Asparagus acutifolius & Liliacées & Ge & L.V & Méd. \\
\hline Asparagus albus L. & Asparagus albus & Liliacées & Ge & L.V & W. Méd. \\
\hline Asparagus stipularis Forssk. & Asparagus stipularis & Liliacées & Ge & L.V & Macar.-Méd. \\
\hline Pallenis maritima (L.) Greuter & Asteriscus maritimus & composées & Ge & H.V & $\begin{array}{l}\text { Canaries, Eur. mérid. } \\
\text { A.N. }\end{array}$ \\
\hline Astragalus echinatus Murray & Astragalus pentaglottis & Papilionacées & Th & H.A & Méd. \\
\hline Atriplex dimorphostegia Kar. \& Kir. & Atriplex dimorphostegia & Chénopodiacées & $\mathrm{Th}$ & H.A & Sah-Sind \\
\hline Atriplex glauca L. & Atriplex glauca & Chénopodiacées & $\mathrm{Ch}$ & L.V & Sah-Méd. \\
\hline Atriplex halimus L. & Atriplex halimus & Chénopodiacées & $\mathrm{Ch}$ & L.V & Cosmop. \\
\hline Avena cf. barbata Pott ex Link & Avena alba & Graminées & Th & H.A & Méd-Irano-Tour. \\
\hline Avena sterilis L. & Avena sterilis & Graminées & Th & H.A & Macar-Méd-Irano-Tour. \\
\hline
\end{tabular}




\section{Continued}

\begin{tabular}{|c|c|c|c|c|c|}
\hline Ballota hirsuta Benth. & Ballota hirsuta & Labiées & $\mathrm{Ch}$ & H.V & Ibéro-Maur. \\
\hline Bellis annua $\mathrm{L}$. & Bellis annua & Composées & Th & H.A & Circumméd. \\
\hline Brachypodium distachyon (L.) P.Beauv. & Brachypodium distachyum & Graminées & Th & H.A & Paléo-Subtrop. \\
\hline Brassica nigra (L.) W.D.J.Koch & Brassica nigra & Crucifères & Th & H.A & Euras. \\
\hline Anisantha rubens (L.) Nevski & Bromus rubens & Graminées & Th & H.A & Paléo. Subtrop. \\
\hline Calendula cf. arvensis L. & Calendula arvensis & Composées & Th & H.A & Sub-Méd. \\
\hline Calicotome intermedia (Salzm.) C.Presl & Calycotome intermedia & Papilionacées & $\mathrm{Ch}$ & L.V & W. Méd. \\
\hline Ceratonia siliqua L. & Ceratonia siliqua & Césalpiniées & $\mathrm{Ph}$ & L.V & Méd. \\
\hline Chamaerops humilis L. & $\begin{array}{l}\text { Chamaerops humilis subsp } \\
\text { argentea }\end{array}$ & Palmacées & $\mathrm{Ph}$ & L.V & W. Méd. \\
\hline Plagius grandis (L.) Alavi \& Heywood & Chrysanthemum grandiflorum & Composées & $\mathrm{He}$ & H.V & End. \\
\hline Cistus albidus L. & Cistus albidus & Cistacées & $\mathrm{Ch}$ & H.V & Méd. \\
\hline Convolvulus cf. althaeoides L. & Convolvulus althaeoides & Convolvulacées & Th & H.A & Macar-Méd. \\
\hline Daphne gnidium L. & Daphne gnidium & Thymelaeacées & $\mathrm{Ch}$ & H.V & Méd. \\
\hline Delphinium peregrinum L. & Delphinium peregrinum & Renonculacées & Th & H.A & Méd. \\
\hline Echinops spinosissimus Turra & Echinops spinosus & Composées & $\mathrm{He}$ & H.V & S. Méd. Sah. \\
\hline Echium & Echium "vulgare" & Boraginacées & $\mathrm{He}$ & H.V & Méd. \\
\hline Erodium moschatum (L.) L’Hér. & Erodium moschatum & Géraniacées & Th & H.A & Méd. \\
\hline $\begin{array}{l}\text { Erucaria pinnata subsp. uncata (Viv.) } \\
\text { Täckh. \& Boulos }\end{array}$ & Erucaria uncata & Crucifères & Th & H.A & Sah-Sind. \\
\hline Fagonia cretica L. & Fagonia cretica & Zygophyllacées & Th & H.A & Méd. \\
\hline Frankenia corymbosa Desf. & Frankenia corymbosa & Frankeniacées & $\mathrm{Ge}$ & H.V & Méd. \\
\hline Frankenia laevis L. & Frankenia laevis & Frankeniacées & Ge & H.V & Paléo-temp. \\
\hline Frankenia thymifolia Desf. & Frankenia thymifolia & Frankeniacées & $\mathrm{Ch}$ & L.V & End. N.A. \\
\hline Fumana thymifolia (L.) Webb & Fumana thymefolia & Cistacées & $\mathrm{Ch}$ & H.V & Euras. Af. Sept. \\
\hline Galactites elegans (All.) Soldano & Galactites tomentosa & Composées & $\mathrm{He}$ & H.V & Circumméd. \\
\hline Globularia alypum L. & Globularia alypum & Globulariacées & $\mathrm{Ch}$ & L.V & Méd. \\
\hline Glyceria fluitans (L.) R.Br. & Glyceria fluitans & Graminées & $\mathrm{Ge}$ & H.V & Sub-cosm. \\
\hline Halogeton sativus (L.) Moq. & Halogeton sativus & Chénopodiacées & Th & H.A & W. Méd. \\
\hline Hordeum leporinum & $\begin{array}{l}\text { Hordeum murinum subsp lepo- } \\
\text { rinum }\end{array}$ & Graminées & Th & H.A & Circumbor. \\
\hline Limonium pruinosum (L.) Chaz. & Limonium pruinosum & Plumbaginacées & Th & H.A & Sah. \\
\hline Lygeum spartum L. & Lygeum spartum & Graminées & $\mathrm{Ge}$ & H.V & W. Méd. \\
\hline Malva aegyptia L. & Malva aegyptiaca & Malvacées & Th & H.A & Sah-Sind. Méd. \\
\hline
\end{tabular}




\section{Continued}

\begin{tabular}{|c|c|c|c|c|c|}
\hline Malva sylvestris L. & Malva sylvestris & Malvacées & Th & H.A & Euras \\
\hline Marrubium vulgare $\mathrm{L}$. & Marrubium vulgare & Labiées & Ch & L.V & Cosmop. \\
\hline Medicago minima (L.) L. & Medicago minima & Papilionacées & Th & H.A & Eur. Méd. \\
\hline Medicago rugosa Desr. & Medicago rugosa & Papilionacées & Th & H.A & E. Méd. \\
\hline Muricaria prostrata (Desf.) Desv. & Muricaria prostrata & Crucifères & Th & H.A & End. N.A. \\
\hline Olea europaea subsp. europaea & Olea europea & Oléacées & $\mathrm{Ph}$ & L.V & Méd. \\
\hline Pallenis spinosa (L.) Cass. & Pallenis spinosa & Composées & $\mathrm{He}$ & H.V & Euro-Méd. \\
\hline Papaver rhoeas L. naturalised & Papaver rhoeas & Papavéracées & Th & H.A & Paléo-Temp. \\
\hline Peganum harmala L. & Peganum harmala & Zygophyllacées & Ch & H.V & Iran-Tour-Eur. \\
\hline Phalaris aquatica L. & Phalaris bulbosa & Graminées & Th & H.A & Macar. Méd. \\
\hline Plantago albicans L. & Plantago albicans & Plantaginacées & $\mathrm{Ge}$ & H.V & Méd. \\
\hline Plantago lagopus L. & Plantago lagopus & Plantaginacées & Th & H.A & Méd. \\
\hline Plantago lanceolata L. & Plantago lanceolata & Plantaginacées & Ge & H.V & Euras. \\
\hline Plantago ovata Forssk. & Plantago ovata & Plantaginacées & $\mathrm{He}$ & H.V & Méd. \\
\hline Reseda alba L. & Reseda alba & Résédacées & $\mathrm{He}$ & H.V & Euras. \\
\hline Salsola flavescens Cav. & Salsola foetida & Chénopodiacées & Ch & L.V & Sah-Sind. \\
\hline Salsola kali L. & Salsola kali & Chénopodiacées & Th & H.A & Paléo-Temp. \\
\hline Salsola glomerata (Maire) Brullo & Salsola sieberi & Chénopodiacées & Ch & L.V & Sah-Sind. \\
\hline Salsola tetrandra Forssk. & Salsola tetragona & Chénopodiacées & Ch & L.V & Sah. \\
\hline Salsola vermiculata $\mathrm{L}$. & Salsola vermiculata & Chénopodiacées & Ch & L.V & Sah-Méd. \\
\hline Salvia verbenaca $\mathrm{L}$. & Salvia verbenaca & Labiées & $\mathrm{He}$ & H.A & Méd.-Atl. \\
\hline Sanguisorba minor Scop. & Sanguisorba minor & Rosacées & Th & H.A & Euras. \\
\hline Lomeliosia stellata (L.) Raf. & Scabiosa stellata & Dipsacacées & Th & H.A & W. Méd. \\
\hline Scolymus hispanicus L. & Scolymus hispanicus & Composées & $\mathrm{He}$ & H.V & Méd. \\
\hline Scorzonera laciniata L. & Scorzonera laciniata & Composées & $\mathrm{Ge}$ & H.V & Sub-méd-Sib. \\
\hline Scorzonera undulata Vahl & Scorzonera undulata & Composées & $\mathrm{Ge}$ & H.V & Sud-méd. \\
\hline Sinapis arvensis L. naturalised & Sinapis arvensis & Crucifères & Th & H.A & Paléo-temp. \\
\hline Spergularia munbyana Pomel & Spergularia munbyana & Caryophyllacées & $\mathrm{Ge}$ & H.V & End. \\
\hline Stipa tenacissima L. & Stipa tenacissima & Graminées & Ge & H.V & Iber-Maur. \\
\hline Suaeda fruticosa (L.) Forssk. & Suaeda fruticosa & Chénopodiacées & Ch & L.V & Cosmop. \\
\hline Tamarix gallica L. & Tamarix gallica & Tamaricacées & $\mathrm{Ph}$ & L.V & N. Trop. \\
\hline Thapsia garganica L. & Thapsia garganica & Ombellifères & Ch & H.V & Méd. \\
\hline $\begin{array}{l}\text { Thymus munbyanus subsp. coloratus (Boiss. } \\
\text { \& Reut.) Greuter \& Burdet }\end{array}$ & $\begin{array}{l}\text { Thymus ciliatus subsp col- } \\
\text { oratus }\end{array}$ & Labiées & Ch & H.V & End. N.A. \\
\hline Trifolium angustifolium L. & Trifolium angustifolium & Papilionacées & Th & H.A & Méd. \\
\hline Ziziphus lotus (L.) Lam. & Ziziphus lotus & Rhamnacées & $\mathrm{Ph}$ & L.V & Méd. \\
\hline
\end{tabular}




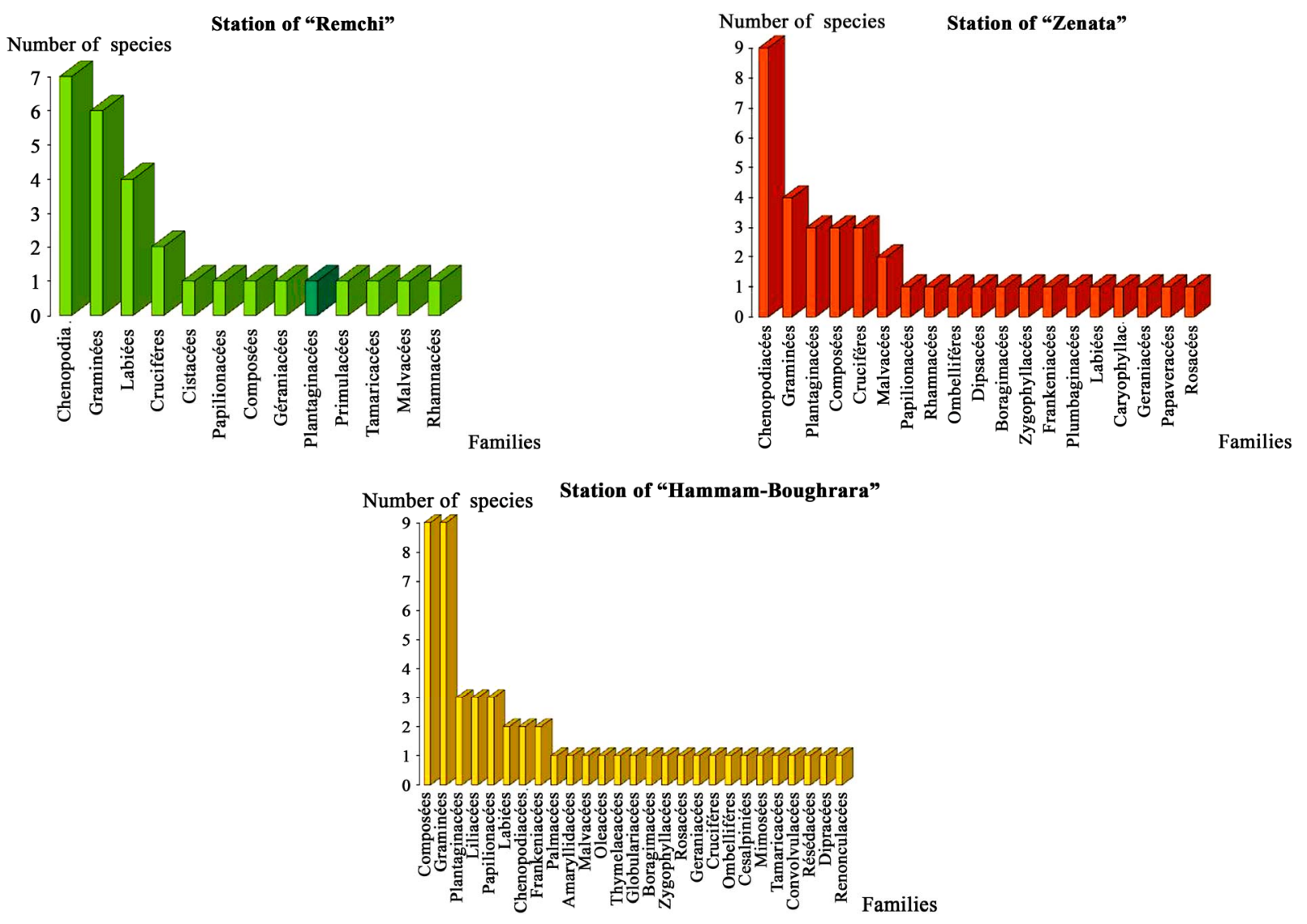

Figure 2. Distribution of species by families.

Table 3. Distribution of species’ number by biological types.

\begin{tabular}{|c|c|c|c|c|c|c|}
\hline \multirow[b]{2}{*}{ Biological types } & \multicolumn{2}{|c|}{ “Remchi” Station } & \multicolumn{2}{|c|}{ “Zenata” Station } & \multicolumn{2}{|c|}{ "Hammam-Boughrara" Station } \\
\hline & Number of species & $\%$ & Number of species & $\%$ & Number of species & $\%$ \\
\hline Therophytes (Th) & 13 & 46 & 19 & 51 & 17 & 33 \\
\hline Chamaephytes (Ch) & 10 & 36 & 9 & 24 & 10 & 19 \\
\hline Hemicryptophytes (He) & 2 & 7 & 4 & 11 & 7 & 13 \\
\hline Geophytes (Ge) & 1 & 4 & 4 & 11 & 13 & 25 \\
\hline Phanerophytes (Ph) & 2 & 7 & 1 & 3 & 5 & 10 \\
\hline
\end{tabular}

As for therophytes, we found Atriplex dimorphostegia, Avena sterilis, Aegilops triuncialis, Papaver rhoeas and Hordeum murinum.

The phanerophytes $(\mathbf{P h})$ are limited to Tamarix gallica. In Hammam Boughrara station, the number of geophytes (Ge) should not be overlooked. During favorable years, the regressive evolution of vegetation appears by extension of geophytes like Stipa tenacissima, Sanguisorba minor, Frankenia corymbosa and Frankenia laevis) and the gradual appearance of hemicryptophytes with rosettes (He) (Pallenis spinosa, Echinops spinosus, Galactites tomentosa, Echium vulgare and Reseda alba).
Finally, the distribution of biological types follows this pattern for the three studied sta tions: $\mathrm{Th}>\mathrm{Ch}>\mathrm{He}>\mathrm{Ge}$ $>\mathrm{Ph}$.

\section{- Biogeographic types}

The distribution of species sampled by phy togeographic element was very heterogeneous in the three stations, although retained a net balance of Mediterranean species (Figure 3). In the Remchi and Zenata stations, SaharoSindian species succeeded the Mediterranean species; it shows climatic worsening related to desert vegetation. For the Hammam Boughrara station, the West-Mediterranean species rejoin the Mediterranean to strengthen the 
group. The strictly endemic species of North African stock were relatively few in number [34].

\section{- Morphological types}

Our study stations' vegetal cover is dominated by perennials and annuals herbaceous with an average percent- age of 75\% (Table 4). Among the morphological types, we can name the following optional or obligatory halophytes: Frankenia corymbosa, Frankenia laevis, Frankenia thymifolia, Lygeum spartum and Halogeton sativus.
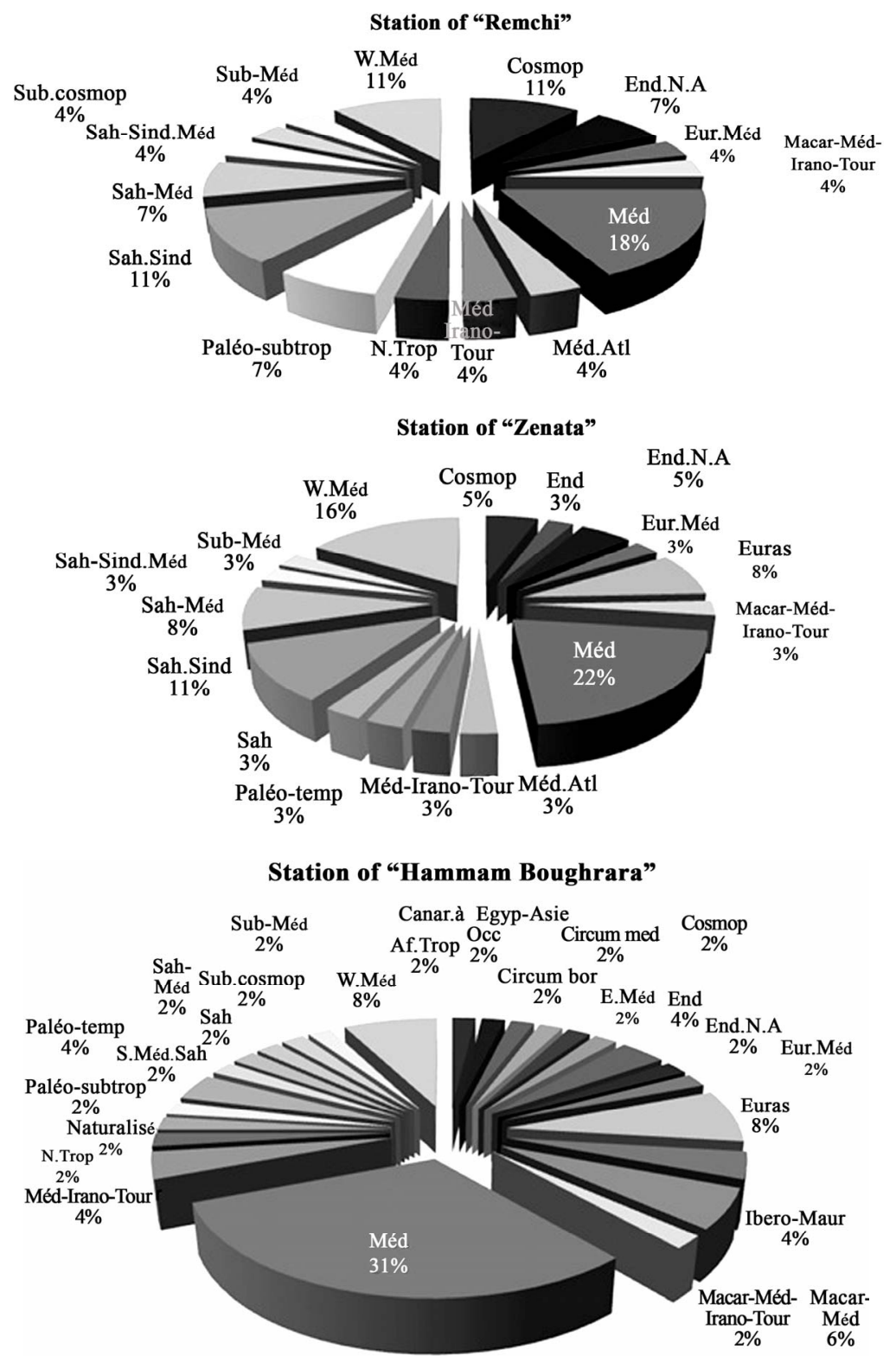

Figure 3. Distribution of species according to the biogeographic types.

Table 4. Distribution of species' number by morphological types.

\begin{tabular}{lcccccc}
\hline \multirow{2}{*}{ Morphological types } & \multicolumn{2}{c}{ “Remchi” Station } & \multicolumn{2}{c}{ “Zenata” Station } & \multicolumn{2}{c}{ "Hammam-Boughrara” Station } \\
\cline { 2 - 7 } & Number of species & $\%$ & Number of species & $\%$ & Number of species & $\%$ \\
\hline Perennials woody (P.W) & 7 & 25 & 8 & 22 & 14 & 27 \\
Perennials herbaceous (P.H) & 7 & 25 & 9 & 24 & 21 & 40 \\
Annuals herbaceous (A.H) & 14 & 50 & 20 & 54 & 17 & 33 \\
\hline
\end{tabular}


Woody perennials are then in the minority with an average of $25 \%$. They are represented, among other species, by the following optional or obligatory halophytes: Tamarix gallica, Atriplex halimus, Salsola vermiculata and Suaeda fruticosa.

Despite the misleading presence of shrubs, it is no longer a pre-forest scrubland, but a degraded scrubland. Note that this scrubland underlines the ultimate degradation of woody vegetation.

\section{CONCLUSIONS}

The study area was installed, according to Emberger climagramme, in the lower semi-arid and higher arid bioclimatic level with cool or temperate winter.

The soils of these halophilic populations have a siltysandy to sandy texture; the organic matter content (up to $2.21 \%$ ) and limestone (up to $27 \%$ ) are relatively low, the $\mathrm{pH}$ is alkaline (above 7.7).

The vegetation analysis helped to clarify the distribution of species and to identify the botanical components. Sustainability between different stations of the region is reflected by the dominance of three families: Chenopodiaceae, Asteraceae and Poaceae.

Flora study shows a clear therophytic and chamæphytic dominance: $33 \%$ and $19 \%$ respectively.

Marked by crop expansion (food crops in green houses), the region suffers from overgrazing. Climatic constraints and lack of rational management of pasture courses contributed to a sharp deterioration in Atriplex halimus and Salsolaceae populations (Salsola vermiculata) and to the disappearance of some taxa.

The settlement of this region shows significant changes in transition groups (mixing, mosaics). Flora is, however, very varied. In addition to the species strictly related to edaphic substrate (gypsum, salt), a large number of species is indifferent to it. Most of the latter belongs to dry and warm habitats, similar to steppes vegetation. One considers if they have morphological characteristics which respond to the adverse effects of atmospheric and soil drought, and to the relatively high levels of gypsum or salts in these soils. This region is also subject to the amplification phenomena of surrounding land salinity, often responsible for spatial variations of the native plant communities.

\section{REFERENCES}

[1] Simonneau, P. (1952) Shoreline vegetation of the sand dunes of Arzew gulf (Damesne-Saint Leu-La MactaOureah). Publication of the General Inspection of Agriculture, Algiers.

[2] Dubuis, A. and Simonneau, P. (1957) Phytosociological units of salted lands in Western Algeria. Works in pedology and agrology sections, Publication of the Hydraulic and Rural Equipment Direction. Scientific Studies Services, Algiers, Bulletin No. 3, 20 p.

[3] Dubuis, A. and Simonneau, P. (1960) Contribution to the study of the halophilous vegetation of closed basins of the Oran plateau. Works in pedology and agrology sections, Publication of the Hydraulic and Rural Equipment Direction, Scientific Studies Services, Algiers, Bulletin No. 11, $115 \mathrm{p}$.

[4] Quézel, P. and Simonneau, P. (1960) Some aspects of the salted lands vegetation of the sub-coastal plains in the Eastern Oranian region. Works in pedology and agrology sections, Publication of the Hydraulic and Rural Equipment Direction, Scientific Studies Services, Algiers, Bulletin No. 6, 27 p.

[5] Braun-Blanquet, J., Roussine, N. and Nègre, R. (1952) The vegetation of the Mediterranean France. National Center of Scientific Research and Service of North Africa Vegetation Map, Vaucluse, 297 p.

[6] Boulaine, J. (1957) Study of the Chélif plains soils. Works in pedology and agrology sections No. 7: Regional study, Scientific Studies Services, Printing Edition, the Typo-Litho, Algiers, 582 p.

[7] Gaucher, G. and Burdin, S. (1974) Geology, geomorphology and hydrology of the salted lands: Contribution to salted lands enhancement. Live Technics collection, Volume 5: Tropical agronomy section, France University Press.

[8] Ghezlaoui, B.E. (2011) Biomorphology and polymorphism of few halophytes aerial devices in Oranian region, case of Atriplex halimus L. and Tamarix gallica L.. Ph.D. Thesis in Biology, Tlemcen University, Tlemcen.

[9] Aboura, R. (2011) Contribution to the study of the "atriplexaie" in Western Algeria, physiognomic and phytodynamic aspects. Ph.D. Thesis in Biology, Tlemcen University, Tlemcen.

[10] Merzouk, A. (2010) Contribution to the phyto-ecologic study of halophylous stands in the North of Oranian region. Ph.D. Thesis in Biology, Tlemcen University, Tlemcen.

[11] Bemmoussat, F.Z. (2004) Bioclimatic and physiognomic relationships of halophylous stands. Magister Thesis in Biology, Tlemcen University, Tlemcen.

[12] Emberger, L. (1945) Climates biogeographic classification. Collection of Botanical geological and Zoological laboratories works, Montpellier Faculty of Sciences, Bot7, 3-43.

[13] Simonneau, P. (1961) Irrigation studies centers of the Western Sahara. Tests and studies of the 1957-58 and 1960 campaign. Works in agrology and pedology sections, Scientific Studies Services, Algiers, Bulletin No. 6-7.

[14] Ruellan, A. (1971) Contribution to the knowledge of Mediterranean regions soils: Soils with differentiated limestone profile from the plains of the lower Moulouya (East Morocco). Collection, ORSTOM memory, 54, Office of Scientific and Technical Research, France.

[15] Pouget, M. (1980) Soil-vegetation relations in the SouthAlgiers region steppes. Ph.D. Thesis, Aix-Marseille III University, Marseille. 
[16] Alcaraz, C. (1982) The vegetation of the Western Algerian. Ph.D. Thesis, Perpignan University, Perpignan.

[17] Aimé, S. (1991) Ecological study of the transition between the sub-humid, semi-arid and arid populations in the thermo Mediterranean floor of the Oranian Tell (North western Algeria). Ph.D. Thesis, Aix-Marseille III University, Marseille.

[18] Benabadji, N., Bouazza, M., Metge, G. and Loisel, R. (1996) Description and aspects of soils in semiarid and arid region South of Sebdou (Oranian region, Algeria). Bulletin of the Science Institute of Rabat, 20, 77-86.

[19] Guinochet, M. (1973) Phytosociology. Ecology collection, Masson and Cy., Paris, 227 p.

[20] Quézel, P., Barbero, M., Benabid, A. and Rivas-Martinez, S. (1992) Contribution to the study of the forest and preforest groups of the Eastern Morocco. Studia Botanical Review, 10, 57-69.

[21] Braun-Blanquet, J. (1951) Pflanzensociologie. Grundzuge der vegetationskunde. 2nd Edition, Springer, Vienna.

[22] Raunkiaer, C. (1934) The life form of plants and statistical plant geography. Clarendon Press, Oxford.

[23] Quézel, P. and Santa, S. (1962-1963) New flora of Algeria and southern desert regions. 2 Volumes, National Center for Scientific Research, Paris.

[24] Ozenda, P. (1958) Flora of Northern and central Sahara. National Center for Scientific Research, Paris.

[25] Ozenda, P. (1977) Flora of the Sahara. 2nd Edition, National Center for Scientific Research, Paris.

[26] Bonnier, G. (1990) The great flora in color. Belin Edition, Paris.

[27] Braun-Blanquet, J. (1947) The vegetation cover in the
Montpellier region and its relationship with soil. Sigma Communication (Support for Improvement of Governance and management Programme), 94, Montpellier.

[28] Braun-Blanquet, J. (1931) Overview of the lower Languedoc vegetation. Sigma Communication (Support for Improvement of Governance and management Programme), 9, Montpellier, 35-40.

[29] Raunkiaer, C. (1905) Biological types for botanical geography. KLG. Danskee Vidennskabenes Selskabs, Farrhandl, 5, 347-437.

[30] Dahmani, M. (1997) The green oak in Algeria, stands' syntaxonomy, phyto-ecology and dynamic. Ph.D. Thesis, Sciences and Technologies Houari Boumediene University, Algiers.

[31] Benabadji, N. and Bouazza, M. (2002) Contribution to the study of the steppe floristic procession in the South of El-Aricha (Oranian region-Algeria). Science and Technologies Journal of the University of Constantine, special issue, 11-19.

[32] Orshan, G., Montenegro, G., Avila, G., Aljaro, M.E., Walckorviak, A. and Mujica, A.M. (1984) Plant growth forms of Chilean Matorral. A monocharacter growth form analysis along an altitudinal transect from sea level to $2000 \mathrm{~m}$ a.s.l. Bulletin of the Botanical Society of France, Botanic Actualities, 131, 411-425.

[33] Floret, C., Galan, M.J., LeFloch, E., Orshan, G. and Romane, F. (1990) Growth forms and phenomorphology traits along an environmental gradient: Tools for studying vegetation. Journal of Vegetation Science, 1, 71-80. doi: $10.2307 / 3236055$

[34] Quézel, P. (2000) Reflection on the flora and vegetation evolution in the Mediterranean Maghreb. Ibis press, Paris. 


\section{APPENDIX}

Tables 1, 2 and 3: Floristic inventories of the 3 study sites.

“Zenata” Site

Place : Zenata

Altitude (m)

Slope (\%)

Geom. substrate

Recovery level (\%)

Number of inventories

Species

Caracteristics of Nitratophiles: Stellarietea-mediae

Erodium moschatum

Papaver rhoeas

Sanguisorba minor

Avena alba

Calendula arvensis

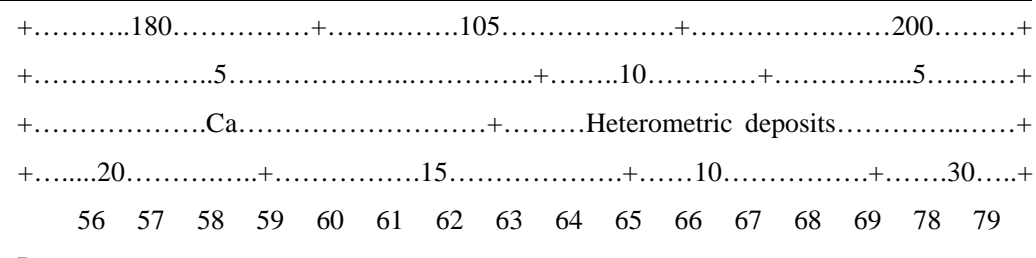

Pres.

Caracteristics of Atriplico halimi-Suaedetum fruticosae

Atriplex halimus

Salsola vermiculata

Salsola foetida

Salsola sieberi

Halogeton sativus

Plantago ovata

Aeluropus littoralis

Suaeda fruticosa

Erucaria uncata

Echium vulgare

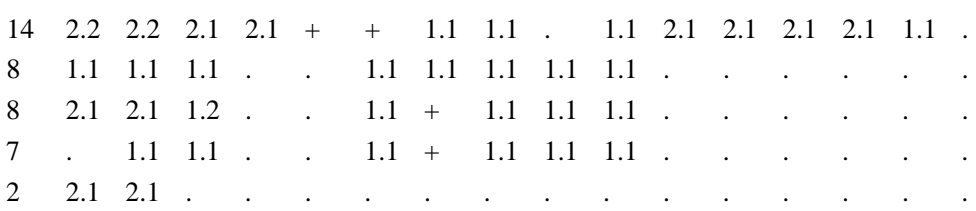

\section{Caracteristics of Salsolo-peganion}

Atriplex dimorphostegia

Arthrophytum scoparium

Peganum harmala

Plantago albicans

Atriplex glauca

Frankenia thymifolia

Limonium pruinosum

Lygeum spartum

Muricaria prostrata

Salvia verbenaca

Spergularia munbyana

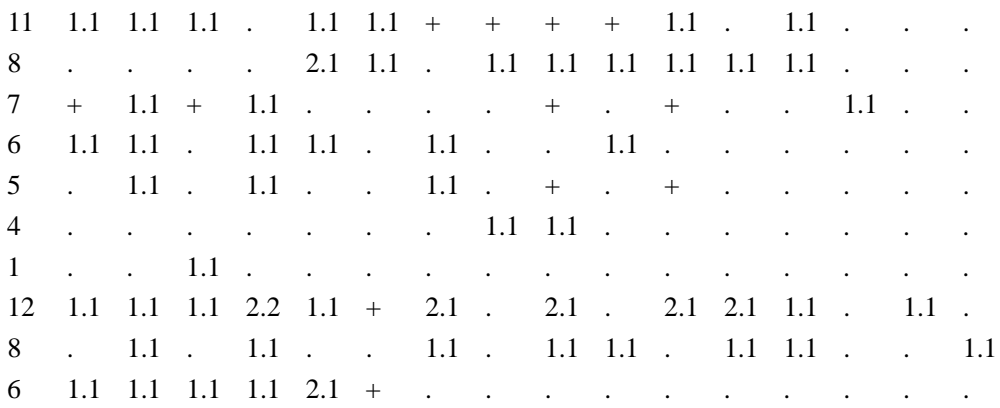

\section{Species “compagnes”}

Malva aegyptiaca

Astragalus pentaglottis

Ziziphus lotus

Ammoides verticillata

Malva sylvestris

Bellis annua

Scabiosa stellata

Plantago lagopus

Avena sterilis

Pallenis spinosa

Brassica nigra

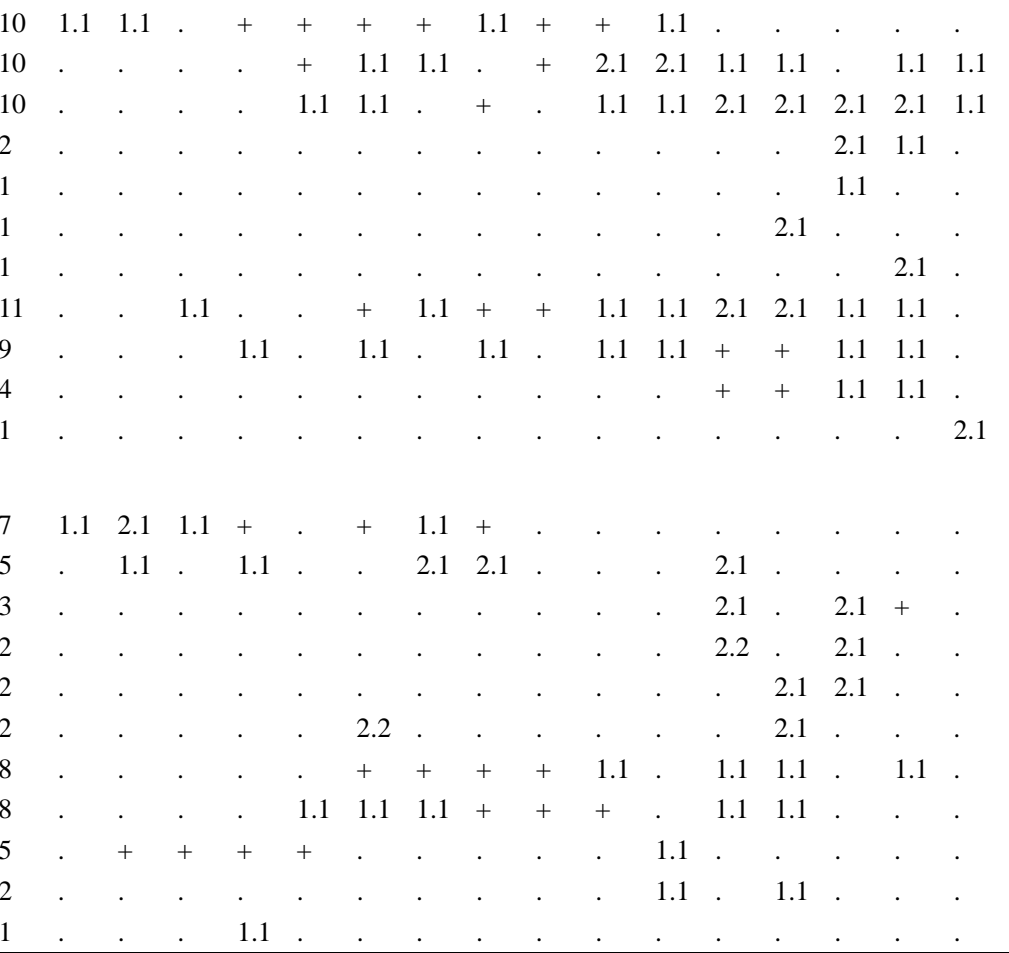


“Remchi” site

Place: Remchi

Altitude (m)

Slope (\%)

Geom. substrate

Recovering level (\%)

Number of inventories

Species

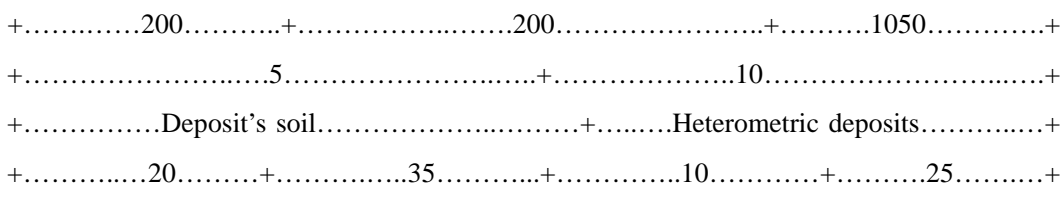

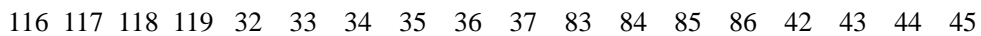
Pres.

Caracteristics of Ononido-Rosmarinetea

Teucrium polium

Ampelodesma mauritanicum

Cistus albidus

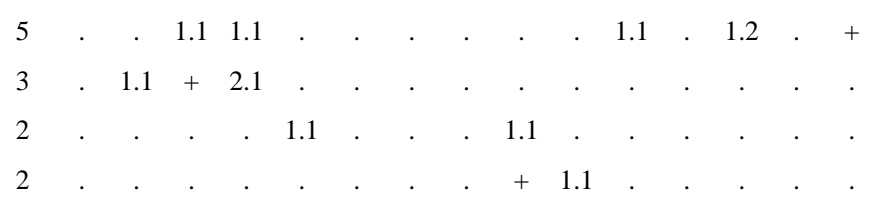

Caracteristics of Nitratophiles: Stellarietea mediae

Astragalus pentaglottis

Muricaria prostrata

Salvia verbenaca

Calendula arvensis

Marrubium vulgare

Erodium moschatum

$\begin{array}{ccccccccccccccc}6 & . & 1.1 & 1.1 & . & . & 2.1 & . & 2.1 & . & 2.1 & . & 1.1 & . \\ 6 & . & . & . & 2.1 & 2.1 & . & 1.1 & 1.1 & . & 1.1 & . & 1.1 & . \\ 4 & . & 1.1 & 1.1 & . & . & + & . & . & . & . & 1.1 & . & \\ 4 & . & . & 2.1 & . & 2.1 & . & . & . & 1.1 & . & 1.1 & . & . \\ 2 & . & . & . & . & . & . & . & . & . & 1.1 & . & 1.1 & . \\ 2 & . & . & 1.1 & . & 1.1 & . & . & . & . & . & . & . & .\end{array}$.

Caracteristics of Thero-Brachypodietea

Plantago ovata

Aegilops triuncialis

Brachypodium distachyum

Anagalis arvensis

Bromus rubens

Avena sterilis

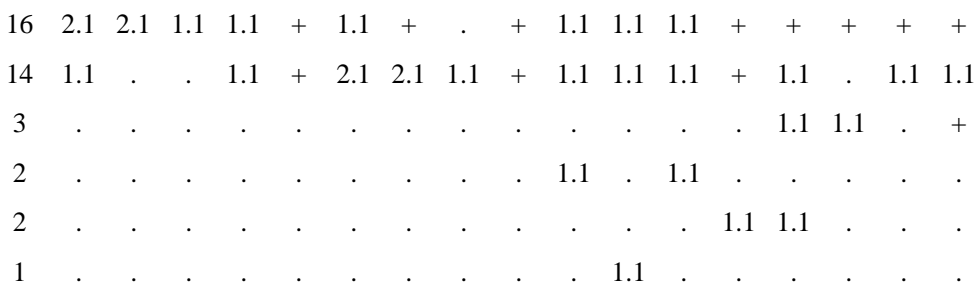

\section{Caracteristics of Salsolatum vermiculatea}

Erucaria uncata

$$
7 \quad \cdot \quad 1.1 \quad 1.1
$$

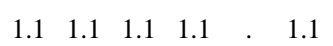

Tamarix gallica

Salsola foetida

Caracteristics of “différentielles”: Atriplico halimi-Suaedetum fruticosae.

Atriplex halimus

$$
7
$$

Suaeda fruticosa

Arthrophytum scoparium

1

\section{Caracteristics of Salsolo-peganion}

Lygeum spartum

Halogeton sativus

Atriplex dimorphostegia

Salsola vermiculata

Species “compagnes”

Malva aegyptiaca 
"Hammam Boughrara” Site

Place : Hammam Boughrara

\begin{tabular}{|c|c|}
\hline Altitude (m) & $\ldots \ldots \ldots . .400 \ldots \ldots \ldots \ldots \ldots \ldots+\ldots$ \\
\hline Slope (\%) & $+\ldots \ldots \ldots \ldots \ldots \ldots \ldots \ldots \ldots \ldots \ldots$ \\
\hline Geom. substrate & ...Thin deposits. \\
\hline Recovering level (\%) & $\ldots \ldots+\ldots$ \\
\hline $\begin{array}{l}\text { Number of inventories } \\
\text { Species }\end{array}$ & $\begin{array}{llllllllllllllllllllllllll} & 1 & 2 & 3 & 4 & 5 & 6 & 7 & 8 & 9 & 10 & 11 & 12 & 13 & 14 & 15 & 16 & 17 & 18 & 19 & 20 & 21 & 22 & 23 & 24 & 25 \\
\text { Pres. } & & & & & & & & & & & & & & & & & & & & & \end{array}$ \\
\hline
\end{tabular}

\section{Caracteristics of Oleo-ceratonion}

Olea europea

Ceratonia silica

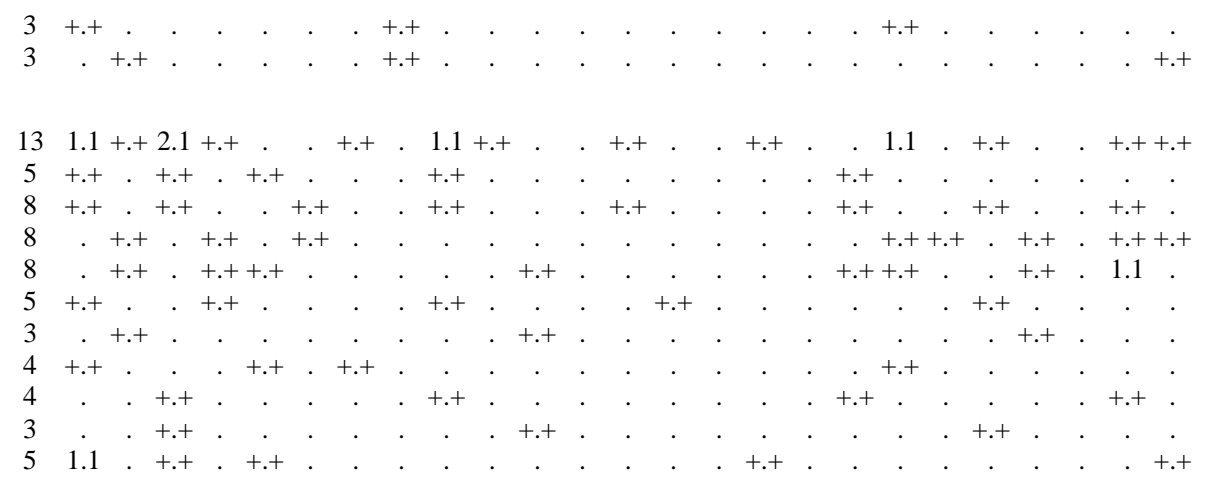

Caracteristics of Rosmarinea officinalis

Agave americana

Asparagus stipularis

Asparagus acutifolius

Artemisia herba-alba

Calycotome spinosa

Asparagus albus

Chamaerops humilis subsp argentea

Daphne gnidium

Globularia alypum

Thymus ciliatus

Stipa tenacissima

Caracteristics of Thero-Brachypodietea

Plantago lagopus

Plantago albicans

Plantago lanceolata

Avena alba

Avena sterilis

Hordeum murinum

Ballota hirsuta

Echinops spinosus

Thapsia garganica

Agropyrum lolium

Pallenis spinosa

Atractylis carduus

Chrysanthemum grandiflorum

Galactites tomentosa

Glyceria fluitans

Calendula arvensis

Malva sylvestris

Scorzonera undulata

Convolvulus althaeoides

Bromus rubens

Phalaris bulbosa

Echium vulgare

Scolymus hispanicus

Fagonia cretica

Sanguisorba minor

Reseda alba

Aegilops triuncialis

Erodium moschatum

Delphinium peregrinum

Caracteristics of Stellarietea-mediae

Scabiosa stellata

Sinapis arvensis

Medicago rugosa

Trifolium angustifolium

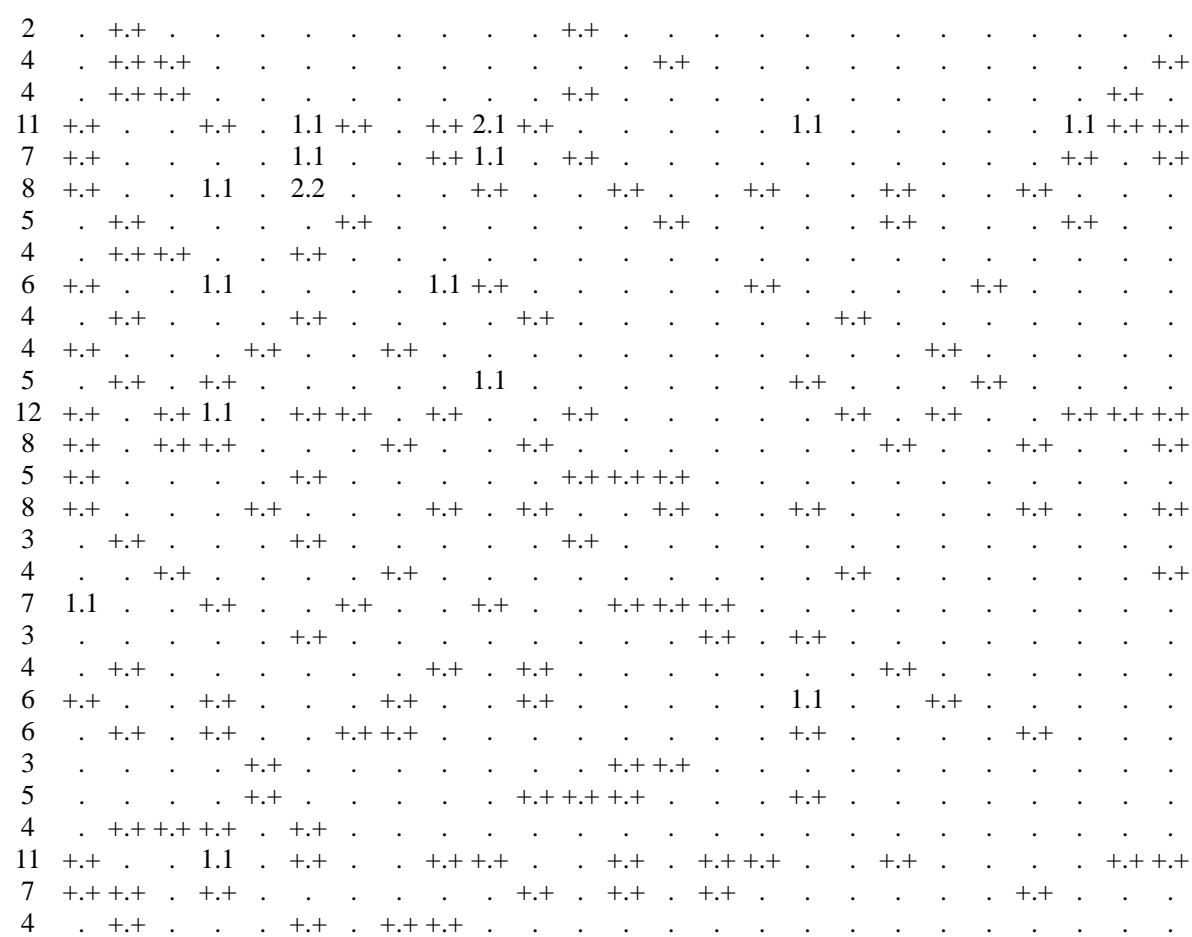

\section{Caracteristics of Salsolatum vermiculatea}

Atriplex halimus

Salsola vermiculata

Tamarix gallica

Frankenia corymbosa

Frankenia laevis

Species “compagnes”

Acacia albida
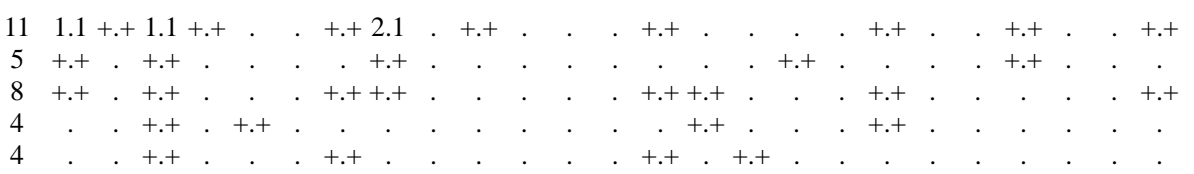